\title{
Universities for sustainability - new challenges from the perspective of the University of Warsaw
}

\author{
Anna Kalinowska, Anna Batorczak \\ University Centre for Environmental Studies and Sustainable Development, University of Warsaw, Żwirki i Wigury Str. 93, 02-089 \\ Warszawa, Poland \\ E-mail address (corresponding author): anna.kalinowska@pro.onet.pl
}

\begin{abstract}
The documents adopted by the international community during the UN Conference on the Environment and Development convened in Rio de Janeiro in 1992 make clear the leading role institutions in higher education are to play in transforming contemporary civilisation in the direction of sustainable development. It is beyond dispute that higher education has a critical role to play in developing tomorrow's decision makers, professionals and citizens. Universities can help with the accomplishment of sustainable development goals if they transform education in this direction, extend their support to interdisciplinary scientific research and ensure the appropriate evolution of the means by which they themselves are managed. However, ensuring that a higher education establishment heads in the direction of sustainability in all academic areas of activity is a difficult process requiring much effort. The article thus presents current international initiatives of the UN in this regard, as well as Higher Education initiatives, alliances and treaties in support of the process, and the objectives and activities of the network of cooperative links between universities that is now taking shape. Also the status of education for sustainable development (ESD) in higher education and existing ESD professional development opportunities for university educators is discussed. In this context, examples of good practice characterising the activity of the University Centre for Environmental Studies and Sustainable Development will serve as a case study.
\end{abstract}

KEY WORDS: sustainability, higher education, Copernicus alliance, university networking, interdisciplinarity, education for sustainable development (ESD)

\section{Introduction}

As Stephen Sterling (2013), Professor of Sustainability Education at Plymouth University and expert of the UNESCO group for the Decade of Education for Sustainable Development has mentioned, it is beyond dispute that higher education has a critical role to play in developing tomorrow's decision makers, professionals and citizens. But the full import of the rapidly changing socio-economic and environmental context within which such roles will be played out lies in the shadows rather than the foreground of higher education discourse, policymaking and practice. There seems to be an implicit assumption that, despite mounting evidence to the contrary, economic futures and ecological futures are, by and large, a matter of continuity, and so we can safely continue to educate for a stable upcoming socio-economic environment, just as in the past (STERLing, 2013).

At the same time, the "People's Sustainability Treaty on Higher Education", an important document prepared by a group of leading international specialists on ESD, has argued that before higher education can genuinely contribute to sustainable development, it must first transform itself. However, transformation is complex and long-term ambition, which must begin by recognising that the sustainable development agenda demands a paradigm shift in education. This is about the transformation of institutional responsibility, as well as the reorientation of curriculum and pedagogy to better serve the needs of current and future generations. This will take time, and a resilient as well as inclusive approach to change (PEOPlE's Sustainability..., 2012). 
The discussion ongoing in Poland as regards the role and functioning of universities also stresses the importance of sustainable development when it comes to shaping the future of these seats of learning.

As KoŚCIELNIAK \& MAKOWSKI (2011) make clear, there is now no way in which knowledge can be conveyed within a single paradigm, or even a single scientific discipline. Rather, the fundamental problems society faces are explained and tackled from interdisciplinary positions. An example would be sustainable development, which requires an approach to the social sciences, but also the biological sciences, and those relating to economics. In the view of the authors cited, the transdisciplinary nature of work also has implications where autonomy issues are concerned. In this case, it would denote institutional freedom as regards the shaping of modules or of research groups, which would be free to act beyond the division into disciplines and Faculties (KoŚCIELNIAK \& MAKOWSKI, 2011).

In the light of the above, it is worth investigating the impact the sustainable development concept has been having on universities, how things look as regards the legal conditioning, what initiatives are being taken in academic circles and what didactic practice this has all borne fruit in.

\section{Education for sustainable development (ESD) in documents}

\subsection{ESD in the documents of the 1992 Rio Earth} Summit

The fact that education for sustainable development should represent an exceptionally important strand, providing horizontal linkage between the environmental, economic and social dimensions was capable of being deduced even at the stage when preparations were being made for the 1992 UN Rio Summit on the Environment and Development. Environmental movements also attached key importance to education, emphasising this in an independent report compiled in advance of the Earth Summit (RAPORTY RUCHÓW..., 1992). This devoted a long paragraph to education, emphasising the need for it to be universal, including also central and local authorities and leading to the harmony between people and nature. These remarks were incorporated into Agenda 21 and into the Convention on Biodiversity and UN Framework Convention on Climate Change, both adopted at the Conference.

Where Agenda 21 is concerned, it was Chapter 36 that included the challenge to promote education, public awareness and training, as well as sustainable development and the protection of the environment. The approach was to manifest itself in three areas of activity: 1) reorienting education towards sustainable development; 2) increasing public awareness; 3 ) promoting training.

All of these spheres should be present in academic activity. Agenda 21 also advocates the establishment of appropriate agencies at national and local level, including for higher-education institutions.

\subsection{Education among the provisions of the Convention on Biological Diversity (CBD)}

Along with the other documents from the Rio Earth Summit, this Convention was adopted and open for signature on June $5^{\text {th }} 1992$. It brings together in a functioning whole several mutually augmentative tasks. These include the protection of all life's biodiversity at all levels from the genetic to that of the ecosystem, the introduction of the principle of sustainable use of the natural resources of our planet and a fair sharing of the benefits arising out of the utilisation of genetic resources. Unlike other international treaties seeking to achieve the better protection of nature, this Convention also addresses economic issues arising out of the utilisation of natural resources. The wealth of different matters covered by the Convention ensures the involvement of literally all sectors of the economy and spheres of public life, up to and including culture and religion. Education - which must in connection with the above address intersectoral matters requiring the involvement of partners from different subject areas - is the subject of Article 13 of the CBD, which provides for the promoting of understanding and public awareness. This article recommends that educational activity be engaged in, as directed at society and with an active inclusion of biodiversity-related subject matter at all levels of the education system. This appeal was also directed at states' governments and educational establishments.

\subsection{The place of education in the UN Framework Convention on Climate Change}

This Convention also stresses the Parties' obligations as regards awareness-raising, with relevant tasks being presented in Article 6. This calls for the implementation of relevant education and training programmes, seeks to ensure access to information on the environment, and encourages the training of staff, as well as joint action and exchanges of experience internationally. The adopted 
work plan in relation to Art. 6 requires that each country prepare programmes suitable for different groups in society, and recommends the creation of activity lists at national level. In Poland, the obligation that universal awareness of climate change and its consequence and means of prevention be instilled more widely is inter alia a matter for institutions in higher education.

\subsection{The place taken by ESD in Polish domestic} documents and acts of law

Alongside the international obligations binding upon Poland but arising out of ratified agreements and Conventions, there are a series of nationallevel documents emphasising the importance of education in the spirit of Rio, and requiring that such education be introduced.

Relevant provisions in this sphere are to be found in such documents and regulations as:

1) The National Environment Policy in the Years 2009-2012 and with a Perspective up to the year 2016;

2) The Nature Conservation Act (Section VIII);

3) The Act on Access to Information on the Environment;

4) The National Environmental Education Strategy;

5) The National Strategy for the Protection and Sustainable Use of Biological Diversity.

In each of the laws or documents mentioned there are references to the need for education and a social dialogue, as well as for access to information, in order that the public might be motivated and mobilised to play an active part in protecting the environment and nature (KALINOWSKA, 2013a).

\subsection{Polish and international strategies and action plans designating directions to ESD}

All of the international accords adopted in the course of the Earth Summit require State Parties to draw up relevant plans and strategies by which Convention provisions are to be brought into force. Alongside the aforementioned action plans and local Agenda 21s prepared at various levels and also embracing educational issues within their scope, there has also been a separate Polish document devoted solely to education for sustainable development entitled the National Environmental Education Strategy, with the subtitle "Through education to sustainable development", this denoting a certain evolutionary change to the approach taken. In the part devoted to academic institutions and ESD, it is the economic and social dimension that is stressed. "1. Environmental education at academic level should present the basic knowledge of natural science, economics, technology and humanities, as well as develop environment-friendly attitudes. 2. Academic institutions should become centres offering post-graduate programmes and courses for teachers, government employees, journalists and other people responsible for - and interested in - environmental issues" (NATIONAL..., 2001).

This direction to education is expounded even more clearly in the next document adopted: the Strategy on Education for Sustainable Development , which is ultimately under the aegis of the UN Economic Commission for Europe. As the document itself asserts, implementation of this strategy should be regarded as an ongoing, unceasing process. However, a problem here lies in the fact that no indicators have yet been devised to determine the overall scale and scope of action to be taken.

The education of the public and society also has its key place in the long-term strategies and work plans associated with each of the Conventions done at Rio. The relevant points there relate to issues of awareness-raising and shaping, with there being exceptionally strong manifestations of this in provisions set out in the Action Plan for the years 2011-2020 adopted during the Conference of the Parties to the Convention on Biological Diversity convened in 2010 (the Aichi Targets). Here Strategic Goal A1 is worded as follows: "By 2020, at the latest, people are aware of the values of biodiversity and the steps they can take to conserve and use it sustainably".

The EU has taken up this challenge, while adjusting it more closely to the situation in our region. A document entitled Our life insurance, our natural capital: an EU biodiversity strategy to $2020^{1}$ was adopted by the Council in May 2011, and sets out in detail the directions society's better education are to take. One of the most novel and innovative ideas in this regard is the "Partnership for Diversity", which is to say the citizen's inclusion at all stages of Strategy implementation, for example in regard to participation in universal biodiversity monitoring.

\subsection{International initiatives devoted to the promotion and dissemination of ESD}

At the request of the Secretariat to the Convention on Biological Diversity, the UN first

\footnotetext{
${ }^{1}$ Communication from the Commission to the European Parliament, the Council, the Economic and Social Committee and the Committee of the Regions. Our life insurance, our natural capital: an EU biodiversity strategy to 2020.
} 
declared 2010 the International Year of Biodiversity, and then made the whole decade 2011-2020 the UN Decade on Biodiversity. Such initiatives have as their aim a long-term focusing of public interest on matters of the threats to nature, as well as the encouragement of the mobilisation of resources necessary for awareness-building. Of particular mobilising significance was the announcement of the UN Decade on Education for Sustainable Development (DESD) for the period 2005-2014. This decade was to inspire a joint search for new goals and tasks, as well as the determining of new standards for education that will be necessary if the fundamental problems of humanity are to be faced up to. In turn, a strategic objective here has been to ensure that attention be paid to the role of education in the achievement of sustainable development. A further key challenge was the raising of the quality of learning and teaching on sustainable development, including at university level. Much in the propagation of these initiatives was to be done by higher education institutions themselves, this still begging a wider question as to the extent to which these opportunities have actually been taken full advantage of (KALINOWSKA, 2010, 2014).

\section{Academic initiatives in the name of SD}

An historic attempt to define and promote sustainability in higher education was made in 1990 in Talloires in France where twenty-two university presidents and chancellors created the Talloires Declaration of University Leaders for Sustainable Future ${ }^{2}$ as the result of The Presidents Conference. The Talloires Declaration has inspired other declaration from university otganizations in 1991 The Halifax Declaration has been agreed as follow up to the Halifax Conference on University Action for Sustainable Development ${ }^{3}$.

Academic circles were rather quick to react to what was called for in the UN documents adopted at the Rio Earth Summit in 1992. A few months later at Swansea, Wales, in August 1993 the Swansea Declaration $^{4}$ was released at the conclusion of the Association of Commonwealth Universities

\footnotetext{
2 ULSF University Leaders For a Sustainable Future:Talloires Declaration http://www.ulsf.org/programs_talloires_history.html 3 Creating a Common Future: An Action Plan for Universities Follow up to the Halifax Conference on University Action for Sustainable Development, December 9-11,1991. Halifax: Lester Pearson Institute for International Development, Dalhousie University, 1992. "http://www.iisd.org/educate/ declarat/actionpl.htm

4 The Swansea Declaration:https;//www.iisd.org/educate/ declarat/actionpl.htm
}

Conference. Also in 1993 COPERNICUS Alliance was established with the European University Association acknowledging the critical role universities would be playing in advancing Agenda 21. COPERNICUS CAMPUS and the COPERNICUS Charta were then launched in Geneva (Copernicus-alliance.org). Until 2005 the document was signed by 326 universities. In 2011 a redesigned version was released as 'COPERNICUS Charta 2.0'5. The COPERNICUS Alliance - or European Network on Higher Education for Sustainable Development - is a network of universities and colleges committed to a transformation of learning and to change in the name of sustainable development. It has a long history and established reputation for its work in incentivising the higher-education sector in Europe to engage more effectively with the sustainability agenda. Working in partnership with strategic stakeholders, the Alliance seeks to inform higher-education policy developments, international initiatives such as the global Action Programme on ESD and UNECE ESD Competences, as well as to support individual institutions in their efforts to lead change in the direction of sustainability. In 2010, the COPERNICUS Alliance was launched as a network, with the aim of bringing together signatories of the Charta and other organisations across Europe to rethink the role of higher education, and to embed sustainability at the core of the European higher-education system.

Within the framework of the COPERNICUS Alliance, ${ }^{6}$ and also during international summits in support of SD, a number of programme documents and declarations (e.g in 2001. The Lüneburg Declaration on Higher Education for Sustainable Development ${ }^{7}$ ) have come into existence in connection with the idea of academic circles engaging actively in sustainable development. The most important of these came into being at the end of the UN Decade of Education for Sustainable Development 2005-2014, i.e. the Higher Education Sustainability Initiative for Rio+20, and then the Rio+20 People's Sustainability Treaty on Higher Education ${ }^{8}$, which was launched at the UN United Nations Conference on Sustainable Development in Rio de Janeiro in June 2012. The key features of these declarations were continued with and expanded in the Nagoya

\footnotetext{
5 COPERNICUS Charta http://copernicus.betawerk.eu/elgg/pg/ pages/view/35/

${ }^{6}$ COPERNICUS Alliance http//www.copernicus-alliance.org

7 The Lüneburg Declaration on Higher Education for Sustainable Development:portal.unesco.org/education/en/files/37585/

11038209883/LuneburgDeclaration.pdf

8 Ibidem
} 
Declaration on Higher Education for Sustainable Development. This Declaration was adopted by the participants at the International Conference on Higher Education for Sustainable Development: Higher Education Beyond 2014, as held in Nagoya, Japan on 9 November 2014 (Nagoya Declaration 2014). This reaffirms the responsibility of higher education for the pursuit of sustainable development, and commits their support to further advancing sustainable development through relevant education. The participants and supporters of the International Conference and the associated University Student Summit on ESD reaffirmed previous relevant commitments, including those made within the framework of the UN Decade of Education for Sustainable Development 2005-2014, the Higher Education Sustainability Initiative for Rio+20, the Rio+20 People's Sustainability Treaty on Higher Education and the IAU Iquitos Statement on Higher Education for Sustainable Development. This means that the higher-education community will continue the reorientation of education towards sustainable development. Acknowledging the responsibility that the community in question bears in the international pursuit of sustainable development via the pathway of education for sustainable development, signatories to the Declaration express their will to continue with successful initiatives that have been developed throughout the UNDSD. More specifically, since Rio+20; setting new goals that support a realignment of economic, social, cultural, environmental and educational frameworks in the spirit of the Sustainable Development Goals (SDGs). With this Declaration, signatories call upon world leaders to support the transformative role of higher education towards sustainable development, and commit to work together and further promote transformative learning and research by encouraging multi-stakeholder, multi-sector partnerships; communicating examples of sustainability practices; promoting broad and strong leadership and public awareness of the values of sustainable development and education for sustainable development; and recognizing the essential role and responsibility of higher education institutions towards creating sustainable societies.

There is no way of mentioning the numerous initiatives jointly seeking to achieve the sustainable development of higher-education institutions, or the conferences concerned with teaching, summer schools or seminars, most especially those offering examples of solutions within the Sustainable Campus framework.

There has also been a dynamic increase in the number of scientific publications devoted to sustainability issues and research into sustainable development. However, it has not been typical for these to be targeted at matters academic. For this reason there has been a need for some journal that would assist the flow of information and exchange of experience with reference to the specific nature of sustainable-development issues, as these are viewed from the point of view of higher education. Such a role is now being played by the International Journal of Sustainability in Higher Education 9 : the first international scholary publication to specifically address the need for documentation and dissemination of research, studies and projects on sustainability matters at higher education institutes.

\section{Academic networks for SD}

The challenges faced by the introduction of sustainable development at universities are frequently similar, irrespective of country or even continent. Hence the ever-more-frequent initiatives seeking joint means by which problems can be resolved and a network for cooperation over particular projects put in place. This is connected with the exchange of experience and research on the degree of advancement of the implementation process when it comes to both teaching and the overall operations of higher-education institutions.

It is worth devoting some space here to two such cooperation programmes - all the more so given their broad scope, as well as the high level of familiarity with them possessed by the present authors, in line with their active participation.

\subsection{University Educators for Sustainable Development (UE4SD)}

This is a project bringing together 55 partners (mainly universities) from 33 countries across Europe and beyond to rethink the higher-education curriculum to address sustainable development. The 3 year-project, funded by the European Commission under the Lifelong Learning Programme - Erasmus Academic Networks, is focusing on linking ESD and the drive to improve quality in higher education generally. UE4SD aims to innovate academic practice and curricula by creating opportunities for university educators to develop professional competences and the academic leadership capabilities linked to Education for Sustainable Development. In other words, it will support teaching colleagues, to enable them to

\footnotetext{
9 Journal of Sustainability In Higher Education http// www.emeraldgrouppublishing.com/products/journals/IJSHE
} 
prepare students, regardless of their courses or specialisation, to understand and apply their professional and global responsibilities in sustainability. Ultimately, it seeks to contribute to the reorientation of higher education so that it is more future-facing, and genuinely able to support the construction of a better world.

The project focus is innovative, as not much is known about how the Education for Sustainable and it is closely associated with the COPERNICUS Alliance. The project is led by the University of Gloucestershire (UK), which works very closely alongside three core partners: the Autonomous University of Madrid (Spain), Charles University (Czech Republic) and Leuphana University of Lüneburg (Germany). The University of Warsaw is represented by the University Centre for Environmental Studies and Sustainable Development as an UE4SD partner, and will be sharing and comparing professional experiences with other partner institutions, seeking to drive curriculum change for sustainability through a focus on Education for Sustainable development capabilities.

This project was in fact commenced with in October 2013 and is divided into three stages:

I. Reviewing the state of the art and identifying leading practice (2014).

II. Developing resources (2015-16).

III. Developing an Academy for ESD in HE (2015-16).

\subsubsection{The state of the art, and existing ESD Professional development opportunities}

The first phase of the project is already finished. It involved each country completing a mapping template to capture the status of ESD in higher education at the national level, as well as to identify existing ESD professional development opportunities for university educators. The mapping template included the following information:

1) Status: captures background information on the status of ESD in higher education at the national level, as well as key policies, resources and initiatives which support its development.

2) Initiatives: provide an overview of initiatives at the institutional and at the professional level to support the professional development of university educators in ESD.

3) Potential case studies: document two or three key initiatives that directly support the professional development of university educators in ESD. They include details about purpose, focus, the pedagogical approach, type of initiative, target groups, and motivations to participate.
4) Reflection: provides a short reflective piece on strategies going forward to improve professional development opportunities for university educators.

The template and the guidelines for collecting the information were developed by the regional coordinators and presented to partners at regional meetings held during February and March 2014 at the different regional hubs. National coordinators submitted the completed template to the regional hub coordinators in May 2014; hence the report reflects the national status and initiatives as of May 2014. The national templates formed one of four regional reports (North, West, South and East Europe) to be compiled by the regional coordinators. Regional reports are generated by summaries in the form of the State of the Art Report ${ }^{10}$. The State of the Art Report reflects the national status and stage reached by initiatives as of May 2014.

In Poland, relevant research was undertaken by the University Centre for Environmental Studies and Sustainable Development. The data for the introductory part were obtained mostly from governmental documents (strategies, policies), and information from official statistical offices in Poland. In terms of national strategies, policies or legislation, which recognise ESD in Higher Education in the partner countries, the NATIONAL EnVironmental Education Strategy. Through EDUCATION TO SUSTAINABLE DEVELOPMENT published by the Polish Ministry of the Environment in 2001 was pointed to as a particularly important document for ESD at academic institutions.

With reference to ESD professional development for university educators within national strategies, it has to be concluded there are no relevant ideas or concepts earmarked specifically for university educators.

The data concerning practices were collected through direct involvement in activities carried out for universities, and institutional contacts. Only one practical activity was identified in Poland. It is an annual conference on Environmental Protection in programmes of Natural Science Studies". The Conference, organised each year by different academic centres, brings together lecturers from all Polish universities with faculties of environmental science. The aim of the conference is to present and discuss the best academic practices in teaching on environmental protection and sustainable development.

\footnotetext{
10 State of the art. report http://www.ue4sd.eu/ images/ RegionalMapping/ UE4SD_State-of-the-art-report.pdf
} 
Analysis of all the national and regional reports show that it is impossible to draw valid conclusions for all participating European countries about the integration of ESD in higher education or the ESD professional development opportunities for university educators, as experiences and perspectives are too varied and context specific. Nevertheless some trends and tendencies can be observed:

1) ESD is gaining importance in higher education.

It can be stated that in almost all UE4SD partner countries guidelines or legislation exists at the national and/or regional level recognizing the importance of ESD in higher education.

2. In many countries, university educators lack ESD professional development opportunities.

Only a few countries have significant programmes oriented to this aim - the United Kingdom is an outstanding example - and in many countries little attention is being paid to the ESD professionalization of university educators. Only a few countries have comprehensive and mandatory programmes for university educators to acquire teaching competences, which would present a favourable context for integrating ESD aspects into professional development programmes. On the contrary, in most countries there are no professional requirements for university educators. As a result it is completely up to the interest and conviction of the individual educator if they will take advantage of professional development opportunities in ESD.

3. University educators address sustainability issues, but do not reflect on their pedagogical approaches.

It seems to be common for university educators to be aware of the importance of sustainable development, and possibly conduct research across many disciplines about sustainability issues, or address sustainability topics in their teaching, but without critically reflecting on their own pedagogical approaches or questioning their own ESD competences.

4. National and regional drivers for ESD in higher education can be identified in the partner countries.

A variety of national, regional, and international networks and partners are active in supporting the integration of sustainability into higher education, which in general is more often the case in the North and the West than in the South and the East regional hubs.

5. University educators need ESD competences.
There is no doubt that university educators need ESD competences, but the national reports do not provide clear information what these competences should be or how they should be acquired.

The results of the mapping exercise described in this state-of-the-art report set the stage for further activities in the UE4SD project. It has been demonstrated that the integration of ESD in higher education, and even the understanding of ESD professional development opportunities, varies according to the cultural and institutional context in the 33 UE4SD European partner countries.

\subsection{Routes towards Sustainability}

Assuming a global dimension is the project entitled Routes towards Sustainability, which is coordinated by the University of Ferrara. Ten universities in Europe, Asia and South America are participating in this project, which has as its aim interdisciplinary didactic and research cooperation linking workers in both the humanities and science, in the area of the sustainable development of contemporary civilisation. The main assumption is that the barriers between fields and between countries should be broken down by way of an academic approach to thinking on the development of civilisation. These assumptions were presented within the framework of this cooperation network at the International Symposium Routing Sustainable Development towards a Culture of Wellbeing (held at Ferrara, 2-4 October 2014). Further activity is associated with the preparation of joint research projects, i.e. concerning the mitigation of natural threats to objects of cultural and natural heritage.

\section{Case study: ESD in the practice of the University Centre for Environmental Studies and Sustainable at the University of Warsaw}

Several educational activities in ESD have been ongoing and are being continued with currently at many Polish and European universities. It is worth mentioning that events such as the UN International Year of Biodiversity 2010 (IYB) and UN DESD 2005-2014 provided the impulse in this case. As an example of good practices let us present the activities of the University Centre for Environmental Studies and Sustainable Development ${ }^{11}$. The Centre is an inter-faculty, interdisciplinary academic unit that carries out research on education and

11 University Centre for Environmental Studies and Sustainable Development http// www.ucbs.uw.edu.pl 
communication on various themes in sustainable development and biodiversity. It was established in 1989 as the University Centre for Environmental Studies as part of the University of Warsaw. The University Centre is a unique scientific and implementation institution in the field of education and policy for the environment and sustainable development, and this fact was manifested still more clearly in 2013 with the change of name to University Centre for Environmental Studies and Sustainable Development. Through wide interFaculty cooperation it engages in a wide range of University activities and lectures for students of Inter-faculty Studies for Environmental Protection. An important activity of the Centre is an open cycle of lectures on "Selected Issues of Sustainable Development" addressed to students from all Faculties, and also journalists, teachers and all interested academic staff.

UCES is a widely-recognised academic unit thanks to its close cooperation with many Polish and European institutions of higher education, teachers' associations, environmental NGOs, the Polish Committee of UNESCO, and the Ministry of the Environment. The Centre develops training programmes and thematic conferences, and participates in the preparation of major national government documents including the Environmental Education Strategies, programmes and expert reports and opinions on different-level school curricula. UCES regularly produces papers and textbooks on education and management for sustainable development, biodiversity and climate change. The Centre's team works on the principle that we cannot expect spectacular successes in ESD until we can disseminate the message widely among various social groups diverse in terms of age, level of education and profession. A good example of such a philosophy is the major campaign "Many Faces of Biodiversity' to increase awareness on biodiversity in Poland and celebrate 2010 IYB. The perception of the events constituting the campaign was forwarded by the patronage of the Minister of the Environment and the Secretary General of the Polish Committee for UNESCO.

The process of raising awareness needs "many faces" in terms of educational methods addressed to different target groups: students from across the numerous Faculties of Warsaw University and academies of fine arts, journalists, teachers, school children, and the general public. To make the term "sustainability" sounder, multimedia and multi-target campaign "symphonies" were designed to increase awareness.

1) The National Conferences "Let's Talk about Biodiversity" in 2010 (KALINOWSKA, 2011) and
"Ideal City - Sustainable City" in 2014 brought together representatives of university, city planners and the media to discuss more effective ways of communicating science in the field of sustainability.

2) Training programmes and workshops for teachers and environmental educators supported pedagogic preparation for ESD.

3) Printed materials as teacher-training manual (BATORCZAK \& KALINOWSKA, 2010), as well as textbooks containing lectures and conference papers designed to support students, teachers and journalists with modern interdisciplinary knowledge on sustainable development (KALINOWSKA, 2010).

The University of Warsaw Centre now pays much attention to the education of senior citizens, preparing teaching materials for numerous Universities of the Third Age across Poland. The evaluation carried out within the target groups directly involved in the activities mentioned confirmed positive effects on familiarity with the terms biodiversity and sustainable development, as well as the links between theory and everyday practice.

\section{Ideal city - Sustainable city. Is it possible to achieve without the engagement of the University?}

As one mission of the universities is to support sustainable urban development, the University of Warsaw in cooperation with Polish Association of Urban Planners has launched a multi-disciplinary project entitled "Ideal city - sustainable city". The aim of the project has been to bring together scientists from different disciplines and urban practitioners to study how to urban air pollution, and especially the growing carbon emissions, might be abated. Carbon emissions represent one of the main challenges for cities, on account of the serious consequences for the climate. To reduce these, solutions were seen to lie in sustainable spatial planning and the support of ecosystem services as achieved by the planting of urban trees and green spaces. The project consisted of a series of events including seminars, panel discussions and conferences engaging different stakeholders. The main achievements of the project were published as the list of practical postulates addressed to the municipal authorities. The Centre is also active at the international level, representing the University of Warsaw in the COPERNICUS Alliance and serving as an active partner in two ESD networks, i.e. Routes towards Sustainability and UE4ESD. 


\section{Conclusions}

Overall, the university activities, projects and declarations presented here confirm the idea that a majority of academic circles are recognising the crucial role and responsibility of higher education institutions to develop students and all types of learners into critical and creative thinkers and professionals, to acquire relevant competences and capabilities for future-oriented innovation in order to find solutions to complex, transdisciplinary and trans boundary issues, and to foster understanding and a putting into practice of collective values and principles that guide attitudes and transformations, respecting the environmental limits of our planet, through education, training, research and outreach activities (STERLING, 2014). However, our own observations go together with the picture emerging from discussions taking place at academic conferences devoted to SD, as well as the results of research, to suggest that, in practice, the effects of implementing sustainable development at institutions of higher education are far from satisfactory (GULIO, 2006; ADOMSSENT, 2006; JONES ET AL., 2010; KALINOWSKA, 2011,2013; KAWA, 2012). For this reason also it would seem that actions need to be taken that are sensitive to the contexts from the local to global levels in which particular sustainability challenges are manifested, with different approaches and solutions being pursued, as well as different models of supporting higher education initiatives promoting science and learning, capacity development, transparency and the continuous enhancement of activities.

\section{References}

Adomssent M., Godemann J., Leicht A., Busch A. (eds.). 2006 Higher Education for Sustainability. VAS. Frankfurt am Main.

Adomssent M. 2006. Higher Education for Sustainability: Challenges and Obligations from a Global Perspective. [in:] Adomssent M., Godemann M., Leicht A., Busch A. (eds.). 2006. Higher Education for Sustainability. VAS. Frankfurt am Main.

Batorczak A., Kalinowska A. 2010. Na spotkanie różnorodności biologicznej. UCBS. Warszawa.

Gulio Di A. 2006. Education for Sustainable Development What Does it Mean and What Should Students Learn. [in:] Adomssent M., Godemann J., Leicht A., Busch A. (eds.). 2006. Higher Education for Sustainability. VAS. Frankfurt am Main.

Europejska Komisja Gospodarcza ONZ. Strategia Edukacji dla Zrównoważonego Rozwoju. [The UN Economic Commission for Europe. Educational Strategy for Sustainable Development] 2008, Ministry of the Environment, Warsaw.
Jones P., Selby D., Sterling S. 2010. Sustainability Education: Perspectives and practice across higher education., Earthscan, London.

Kalinowska A., Lenart W. (eds.). 2007. Wybrane zagadnienia $z$ ekologii $i$ ochrony środowiska. Teoria i praktyka zrównoważonego rozwoju. Uniwersyteckie Centrum Badań nad Środ. Przyr. Warszawa.

Kalinowska A. 2008. Artykuł 13. W poszukiwaniu społecznego wsparcia $w$ zarządzaniu Konwencja o różnorodności biologicznej. Polska praktyka na tle doświadczeń światowych. Agencja Wyd. Arkadiusz Grzegorczyk. Warszawa.

Kalinowska A. 2010. Rola studiów ochrony środowiska w upowszechnianiu międzynarodowych inicjatyw edukacyjnych ONZ. [in:] Gabryś B., Gabryś G. (eds.) Ochrona środowiska w programach studiów przyrodniczych. Uniw. Zielonogórski. Zielona Góra.

Kalinowska A. (ed.) 2011. Wybrane zagadnienia z ekologii i ochrony środowiska. Różnorodność biologiczna w wielu odsłonach. Uniwersyteckie Centrum Badań nad Środ. Przyr., Warszawa.

Kalinowska A., Batorczak A. 2012. Przyszłość jakiej chcemy dla naszych wnuków. 0 zrównoważonym rozwoju dla słuchaczy Uniwersytetów Trzeciego Wieku. Ziemia i Ludzie. Warszawa.

Kalinowska A. 2013a. Prawo a edukacja dla zrównoważonego rozwoju w 20 lat po Rio. Konfrontacja rzeczywistości z zapisami w Konwencjach przyjętych na Szczycie Ziemi. [in:] Galicki Z. Gubrynowicz A. (eds.) 2013. Międzynarodowe prawo ochrony środowiska XXI wieku. Stow. Absolw. Wydz. Prawa i Administracji UW. Warszawa.

Kalinowska A. 2013b. Contemporary Man in Dialogue with the Environment? [in:] Bulletin. Polish National Commission for UNESCO Review. Warszawa: 77-84.

Kawa K. 2012. Realizacja zasad trwałego rozwoju i nastawienie pracowników administracji różnych wydziałów UW do możliwości starania się o certyfikat ekologiczny. Univ. of Warsaw Bachelor's degree thesis. UCBS, Warszawa.

Kościelniak C., Makowski J. 2011. Uniwersytet na rozdrożu. [in:] Kościelniak C., Makowski J. (eds.) Wolność Równość Uniwersytet. Inst. Obywatelski. Warszawa: 10-15.

National Environmental Education Strategy. Through Education to Sustainable Development 2001, Ministry of the Environment, Warsaw.

Raporty ruchów ekologicznych "Brazylia 92" (Świat i Polska). 1992. Inst. na rzecz Ekorozwoju. Warszawa.

Sterling S. 2013. The sustainable university. Challenge and response. [in:] Sterling S., Larch M. and Heather L. (eds.). 2013. The Sustainable University. Progress and prospects. Routleges. London. 